Irrationality in Health Care 



\section{Irrationality in Health Care}

What Behavioral Economics Reveals

About What We Do and Why

\section{Douglas E. Hough}


Stanford University Press

Stanford, California

Song lyrics at the beginning of Chapter 8:

The Song That Goes Like

From MONTY PYTHON'S SPAMALOT

Lyrics by Eric Idle

Music by John Du Prez and Eric Idle

Copyright $\odot 2005$ Rutsongs Music and Ocean Music

All Rights Reserved Used by Permission

Reprinted by Permission of Hal Leonard Corporation

$\left.{ }^{(}\right)_{2013}$ by the Board of Trustees of the Leland Stanford Junior University. All rights reserved.

No part of this book may be reproduced or transmitted in any form or by any means, electronic or mechanical, including photocopying and recording, or in any information storage or retrieval system without the prior written permission of Stanford University Press.

Special discounts for bulk quantities of Stanford Economics and Finance are available to corporations, professional associations, and other organizations. For details and discount information, contact the special sales department of Stanford University Press. Tel: (650) 736-I 782 , Fax: (650) 736-I 784

Printed in the United States of America on acid-free, archival-quality paper

Library of Congress Cataloging-in-Publication Data

Hough, Douglas E., author.

Irrationality in health care : what behavioral economics reveals about what we do and why / Douglas E. Hough.

pages $\mathrm{cm}$

Includes bibliographical references and index.

ISBN 978-0-8047-7797-I (cloth : alk. paper)

ISBN 978-0-8047-9340-7 (pbk. : alk. paper)

I. Medical economics-United States. 2. Medical care-United States.

3. Health behavior-United States. 4. Economics-Psychological aspects.

I. Title.

$\mathrm{RA}_{41 \mathrm{IO}} .53 . \mathrm{H} 66920 \mathrm{I} 3$

$338.4^{\prime} 7362 \mathrm{I}-\mathrm{dc2} 3$

2012039953

Typeset by Thompson Type in Io/I5 Sabon 
D E D I C A T I O N

To Katerina and Kai, who I hope will have a better health system when they need it 
